\title{
Local Governance and Local Knowledge
}

\author{
Deqing Wang \\ College of Politics \& Public Administration, Tianjin Normal University, Tianjin, China \\ Email: fabiowong@163.com
}

How to cite this paper: Wang, D.Q. (2017) Local Governance and Local Knowledge. Open Journal of Business and Management, 5, 415-419. https://doi.org/10.4236/ojbm.2017.53035

Received: April 2, 2017

Accepted: June 16, 2017

Published: June 19, 2017

Copyright (c) 2017 by author and Scientific Research Publishing Inc. This work is licensed under the Creative Commons Attribution International License (CC BY 4.0).

http://creativecommons.org/licenses/by/4.0/ (c) (i) Open Access

\begin{abstract}
With the rapid development of economy and the deepening of the globalization, the competition between countries all over the world is becoming more and more fierce. In order to improve the comprehensive national strength and achieve the development of the nation, a government reform upsurge arises at the historic moment. China has a vast territory, and local governments at various levels are the key to ensure the overall stability and progress of our country. An effective local government can enhance the local advantages and competitive ability, and then improve the overall strength of our country. Of course, an effective local government needs to constantly improve its own knowledge system, so that its governance will be more scientific. This article uses the method of literature review to study the relationship between local governance and local knowledge. And we hope to find ways to improve the ability of local governance. Meanwhile, this article introduces the characteristics of local governance and local knowledge, and analyzes the relationship between local governance and local knowledge, and then it puts forward corresponding suggestions on local governance.
\end{abstract}

\section{Keywords}

Local Government, Governance, Local Knowledge

\section{Introduction}

Local government is an important part of national political system. In China, local government is a grass-root unit which is governing local affairs directly. As a kind of administrative unit, the local government is set up by the central government according to law. There are plenty of local governments in China, and they play a significant role in their region [1].

Local knowledge refers to a knowledge system that is generated in certain contexts (e.g., historical, territorial, ethnic, racial, etc.) and it is recognized, understood and protected in the context [2]. It is the result and achievement of the material and spirit that created and accumulated by the physical and mental 
work of the people in a certain area.

In the 1960s and 1970s, the western countries began to have a significant impact on the social and cultural trends which is called postmodernism. Postmodernism had a great influence on human knowledge and "Local knowledge" was the product of the transformation of the concept of knowledge [3]. Clifford Geertz is the person who studies local knowledge, and in his opinion, the analysis of culture is not an experimental science to seek the law, but an explanation of the meaning. Local knowledge exists originally only as a cultural anthropology academic concept, but now its importance is far beyond the scope of cultural anthropology and we can find it in the frontier research of many subjects.

The reason why I want to finish this article is that local governance has become more and more popular in China, and the importance of local knowledge is becoming more and more concerned. This article has five sections. It includes the introduction of the characteristics of local governance and local knowledge, and the analysis of the relationship between them. At the same time, we give some suggestions to local governance.

\section{The Characteristics of Local Governance and Local Knowledge}

\subsection{The Characteristics of Local Governance}

\subsubsection{Grassroots}

Compared with central government, the local government is more grass-roots and close to people. What's more, it can understand the needs and ideas of people better. In the process of social management, the central government tends to take the whole situation into account and plan accordingly and formulate guiding policies, the implementation of specific policies needs to be completed by local governments [4]. For the local government, the policies they formulated are more targeted and they can meet the requirements of development easily because the local government has a better understanding of the local situation.

\subsubsection{Dominance}

The rise of local governance movement has made the local government's autonomy greatly improved. Local governments play an increasingly important role in the allocation of social resources, the transformation of development methods and the improvement of people's livelihood.

\subsubsection{Distinction}

Governments at all levels have limited in specific areas [5]. Because of the differences in the natural environment, history, culture, geographical location, social customs, and resource conditions in each region, it determines that there are significant differences in different regions. These differences led to the unbalanced development of social economy, income inequality and other issues, so local government must put a high value on the characteristics of the region as well as the needs of public. 


\subsection{The Characteristics of Local Knowledge}

\subsubsection{Regionality}

Local knowledge is a kind of knowledge which is including the relationship between natives and nature, the means of existence and the conditions of survival in a specific geographical area. For thousands of years, the local people gained experiences from working and their daily life, and eventually they formed their own folk culture and the way of dealing with affairs. These symbolic signs also give a regional mark for the region and the people living in this area [6].

\subsubsection{Entirety}

Local knowledge, an essential part of traditional culture, is rooted in the social ideal, practice, system, relation, custom and culture of the native community [7]. A region of people will form a kind of consensus based on their environment and long-term experience. This kind of consensus often runs through all aspects of life, and reflects in its social ideal, the practice behavior and manner, the restraint and the standard, the life custom and so on. Thus each part is formed into a whole.

\subsubsection{Practicability}

Local knowledge is closely related to agricultural culture, human health, bio-diversity conservation, natural management, education and cultural innovation. The native inhabitants are very familiar with the local terrain, climate and hydrology. According to the long-term practice, they form a valuable knowledge system which is useful for the study of production.

\section{The Relationship between Local Governance and Local Knowledge}

\subsection{Local Governance Provides a Platform for the Value of Local Knowledge}

If the local government wants to realize the effective management, it is necessary to take into account the local values and behavior patterns. At the moment, the importance of local knowledge is reflected.

The local governance needs to draw lessons from the local knowledge of the specific region, so that the policy of the local government can be recognized by the majority of the people in the region. Materialist dialectics says that contact is universal, and we should use this point of view to deal with things. Local governments play an important role in the management of local affairs, they need to coordinate and balance the interests of all parties [8]. At that time, they must be aware of the influence of local knowledge, because this kind of knowledge has penetrated into all walks of life. Therefore, local governments should develop appropriate policies based on local knowledge.

\subsection{Local Knowledge Provides Guidance for Local Governance}

China is a multiracial nation. Protecting the diversity of national culture is of 
great significance in the political, economic, cultural and social life [9]. From a political point of view, the protection of cultural diversity is the key to ensuring national stability, and it is also the responsibility of all levels of local government. From an economic point of view, the unique culture within the region can bring some economic benefits to the local [10]. For example, local governments can develop tourism to promote local economic growth and improve people's living standards according to local natural or human conditions. So local knowledge can help local government to find the right direction of development. From a legal point of view, the native soil society has its own set of knowledge about crime and punishment and the solution to the dispute and it provides guidance for local governments to resolve disputes in the jurisdiction [11]. Local governments can resolve disputes through a combination of local remedies within the limits permitted by law.

\section{Suggestions on Local Government's Attitude towards Local Knowledge}

First of all, the local government should pay more attention to the role of local knowledge, and disseminate the importance of local knowledge in governance actively. Meanwhile, the local government should always maintain the management concept of local conditions. Nowadays, mass media is booming. The mass media has become more and more important in policy process and it has the characteristics of rapid communication and wide spread. Therefore, the local government should make use of the mass media to publicize the policy to the local people.

Secondly, the staffs of local government should continue to learn and accumulate the local knowledge within the region, and they should enhance their knowledge accomplishment and maintain a close and friendly relationship with natives. There is no end to learning. The government is the executor of the will of the people and the defender of the interests. Only by approaching the masses, the government can find the demands of the masses. So the staffs of local government are supposed to walk into masses and learn from them.

Then, local governments should be bold in innovation and formulate some policies which meet the needs of the public under the guidance of local knowledge. Innovation is the motive force of social progress [12]. A conventional idea will become an obstacle to social development. The local government should set up a think tank and dare to try and innovate.

Finally, local governments should increase the protection of local knowledge and establish appropriate institutions to protect local knowledge, So as to ensure the inheritance of local knowledge. Local knowledge is internalized in the habits of the local people and is rarely recorded. So local governments must ensure that the local knowledge can be passed on. Perhaps it is a good way that local governments can collect the precious local knowledge and organize them into a book.

\section{Conclusions}

Local government has to face the local complex environment inevitably. As a 
knowledge system in the local area, local knowledge covers all aspects of social life. If local governments can use local knowledge in the management accurately, they will promote the local development. Therefore, the local government should pay full attention to the importance of local knowledge. In the formulation of policies, local governments should take into account the relevant background of the knowledge. At the same time, the staff should strive to learn the relevant knowledge and enhance their understanding of the economic, cultural and other aspects of the management area.

Of course, my article is still lacking. For the purpose of my writing, I hope to highlight the important role of local knowledge in local governance. Everything has two sides. In this article, I do not discuss the negative impact of local knowledge on local governance. And this is the deficiency of my article. So I need to study more deeply.

\section{References}

[1] Zhou, Y.Z. and Pan, L. (2015) Analysis of Local Government Governance. Academics, 11, 232-238.

[2] Ci, R.D.J. and Zhai, Y.J. (2011) On the Formation, Operation and Power Relation of Local Knowledge. Thinking, 6, 11-15.

[3] An, F.H. (2010) On the Value of Local Knowledge. Contemporary Education and Culture, 2, 34-41.

[4] Tang, T.W., Cao, Q.H. and Zheng, Z.W. (2014) Connotation Characteristics and Its Index System of Local Governmental Management Modernization. Chinese Public Administration, 10, 46-50.

[5] Yang, X.L. (2009) A Study of Location Knowledge and Development. Academic Research, 5, 64-69.

[6] Jiang, F. (2012) Ecological Ethics and Survival Wisdom in Local Knowledge. Shandong Social Sciences, 11, 82-87.

[7] Guo, Y. (2010) Local Knowledge: A Free Path to the Academic Autonomy-My Commentary on "Management in China". Chinese Journal of Management, 4, 475488.

[8] Rao, X.P. and Liu, H.X. (2012) Information Institution and Institution Performance-Based on the Perspective of "Local Knowledge". Journal of Southwest University (Social Sciences Edition), 2, 139-144.

[9] Sun, J.X. and Liu, X.J. (2014) A Study on the Inheritance of Traditional Culture and the Protection of Natural Environment from the Perspective of Local KnowledgeA Case Study of the Rainy Tibetan Tourism Villages. Journal of South-Central University for Nationalities (Humanities and Social Sciences), 6, 7-77.

[10] Luo, Y. (2015) Reflections on Indigenous Knowledge in the New Perspective of Contemporary Western Ecological Anthropology. Journal of Yunnan Normal University (Humanities and Social Sciences), 5, 21-29.

[11] Jiang, P. (2015) The Comparison and Inspiration of Local Knowledge Study at Home and Abroad. Qinghai Journal of Ethnology, 4, 59-64.

[12] Hu, N.S. and Dai, X.Y. (2016) Local Governance Innovation Self Propulsion Mechanism: Motivation, Challenges and Remodeling. Chinese Public Administration, 2, 27-32. 
Submit or recommend next manuscript to SCIRP and we will provide best service for you:

Accepting pre-submission inquiries through Email, Facebook, LinkedIn, Twitter, etc. A wide selection of journals (inclusive of 9 subjects, more than 200 journals)

Providing 24-hour high-quality service

User-friendly online submission system

Fair and swift peer-review system

Efficient typesetting and proofreading procedure

Display of the result of downloads and visits, as well as the number of cited articles Maximum dissemination of your research work

Submit your manuscript at: http://papersubmission.scirp.org/

Or contact ojbm@scirp.org 